\title{
Assessment of Soil Fertility in Terms of Essential Nutrients Contents in the Lower Benue River Basin Development Authority Project Sites, Benue State, Nigeria
}

\author{
Ahola David Oklo ${ }^{*}$, Igwe Ageh Armstrong1, Ocheri Maxwell Idoko², Terhemba Simeon Iningev ${ }^{1}$, \\ Akoji Adeka Emmanuel ${ }^{3}$, Rebecca Onyela Oklo ${ }^{2}$ \\ ${ }^{1}$ Department of Chemistry, Benue State University, Makurdi, Nigeria \\ ${ }^{2}$ Department of Geography, Benue State University, Makurdi, Nigeria \\ ${ }^{3}$ Department of Animal Production, Federal University of Agiculture, Makurdi, Nigeria \\ Email: *oklodahola@gmail.com, ocherix@yahoo.com, Igweageharmstrong@gmail.com, iterhemba@bsum.edu.ng, \\ akoji.ae@gmail.com, oklo.rebeca@gmail.com
}

How to cite this paper: Oklo, A.D., Armstrong, I.A., Idoko, O.M., Iningev, T.S., Emmanuel, A.A. and Oklo, R.O. (2021) Assessment of Soil Fertility in Terms of Essential Nutrients Contents in the Lower Benue River Basin Development Authority Project Sites, Benue State, Nigeria. Open Access Library Journal, 8: e7222.

https://doi.org/10.4236/oalib.1107222

Received: February 5, 2021

Accepted: March 30, 2021

Published: April 2, 2021

Copyright $\odot 2021$ by author(s) and Open Access Library Inc.

This work is licensed under the Creative Commons Attribution International License (CC BY 4.0).

http://creativecommons.org/licenses/by/4.0/

\begin{abstract}
The focus on this research work is on soil fertility and involves the consideration of soil organic matter, soil structure, soil microbial population etc. Project sites of Lower Benue River Basin Development Authority (LBRBDA) were evaluated to ascertain the soil fertility levels in terms of their nutrient contents. Data were obtained using Classical methods of analysis. The average soil $\mathrm{pH}$ were in the range of $(5.84 \pm 0.30-6.32 \pm 0.040)$, the soil organic matter content were in the range of $(0.67 \% \pm 0.01 \%-3.21 \% \pm 0.07 \%)$, moisture content $(0.12 \% \pm 0.55 \%-1.15 \% \pm 0.04 \%)$, very good soil porosity $(34 \% \pm$ $0.07 \%-42 \% \pm 0.07 \%)$, electrical conductivity $(31 \pm 0.35 \mathrm{mS} / \mathrm{m}-54 \pm 0.35$ $\mathrm{mS} / \mathrm{m})$, CEC $(2.022 \pm 0.04 \mathrm{meq} / 100 \mathrm{~g}-2.286 \pm 0.002 \mathrm{meg} / 100 \mathrm{~g})$, Base Saturation $(0.246 \% \pm 0.03 \%-0.286 \% \pm 0.004 \%)$, total Nitrogen content $(3.18 \pm 0.01$ $\mathrm{mg} / \mathrm{L}-7.20 \pm 0.14 \mathrm{mg} / \mathrm{L})$, available Phosphorous $(2.57 \pm 0.05 \mathrm{mg} / \mathrm{L}-5.01 \pm$ $0.04 \mathrm{mg} / \mathrm{L})$, with high content of exchangeable Calcium $(19.80 \pm 0.85 \mathrm{mg} / \mathrm{L}-$ $22.04 \pm 0.73 \mathrm{mg} / \mathrm{L})$, exchangeable Potassium $(28.85 \pm 1.45 \mathrm{mg} / \mathrm{L}-29.28 \pm$ $0.91 \mathrm{mg} / \mathrm{L})$, as well as exchangeable Magnesium $(8.62 \pm 0.44 \mathrm{mg} / \mathrm{L}-12 \pm 0.13$ $\mathrm{mg} / \mathrm{L}$ ). Physical parameters fall within the range of a fertile soil; the essential nutrients contents were very high which portrays the soil to be fertile and could support promising vegetable crop yield.
\end{abstract}

\section{Subject Areas}

Edaphology 


\section{Keywords}

Assessment, Lower Benue, Plants, Soil Fertility, Nutrients

\section{Introduction}

Soil serves as the natural habitat of organism and it is the medium through which plants obtain their nutrients. It regulates plants growth, water contents, recycles raw materials etc. Achieving and maintaining optimal levels of soil fertility is paramount importance if agricultural land is to continuously sustain crop production. Soil analysis has been used as an aid to assessing soil fertility, hence, the need for soil analysis. And these have been established in the soil index system widely used all over the world for agricultural purposes. An alternative approach is based on the ratio of certain cation in soil (Base Cation Saturation Ratios) and the use of soil audits are being promoted as better approaches to soil nutrient management. Although the focus on this research work is on soil fertility, managing these properly is only one part of soil management practice which also involves the consideration of soil organic matter, soil structure and soil microbial population [1].

Soil is a naturally occurring ecosystem consisting of a mixture of minerals and organic matter with a definite form, structure and composition. Soil is composed primarily of minerals that are produced from rock (parent material) by the process known as weathering. It has physical, chemical and organic properties which are undergoing changes continuously. It supports a variety of life forms such as microscopic bacterial to higher forms of life including invertebrates such as, moles, voles, spiders, ants, mites, nematodes and earthworms. Soil has four major components namely; mineral matters, air, organic and water [2].

Soil rich in nutrients give rise to fertility of a soil and this might be in different level depending on the soil type and its lack in one more quantity may cause stunted growth of crop plants. The decline or loss of nutrients from soil may be due to the following; During the raining season, there are infiltrations of water into the soil by a process called percolation, as the water passes down the soil, some nutrients are washed away off the soil particle and move down deep to the soil where they may not be available for plant consumption [3]. Generally, soils from up-land leached more so they became less fertile than the soils in the lower level due to the water erodibility and it has been observed that in regions of lower rainfall such as northern states of west Africa, soil leaching is more pronounced than in the humid southern states [4].

Soil nutrients or organic matter present on the top soil can be easily washed away by either surface water run-off or wind and this eventually leads to a great loss of nutrients hence soil fertility decline [5]. When root crops are harvested, nutrients are usually removed from the soil by the harvested roots leading to a certain level of fertility decline. Soil moisture level has pronounced effect on the 
uptake of plant nutrients. As a general rule, there is an increase in the uptake of cations and anions as soil moisture tension is decreased from the permanent wilting percentage to field capacity and when the pores become flooded with water, however roots respiration is affected and ions uptake is decreased [6].

The imbalance in soil nutrient in agricultural sector has drawn a serious concern for soil fertility assessment, these can be traced back to various causes such as; the application of fertilizer to soil by uneducated farmers without making particular reference to the specific need of the soil or plant, uncontrolled continuous erosion, leaching, continuous cultivation on same piece of land on yearly basis and in the riverine areas, the issue of oil spillage on land, over grazing etc. Fertile land is defined as a land that is capable of producing consistently high yield in a wide range of crops [7] [8]. Scientific understanding of soil fertility is also perceived as the status of the soil $\mathrm{n}$ relation to the quantity and availability of required nutrients needed by crops to enhance their growth life. Farmers usually understand fertility in a given soil through their native understanding and long-term experiences in a physical framework particularly color and texture as determinants. Apart from color and texture, other important salient characteristics are rebirths such as organic residues content in the soil, moisture retention capacity, drainage, workability and friability. The farmers in tigray (Ethiopia) use a various observable indicators to assess soil fertility. One of the indicators used for fertility assessment in tigray includes the appearance of specific weed species like Echinips hispidus in Ethiopia [8].

Therefore soil nutrient depletion has grave implication leading to widespread deficiency of macro and micro nutrients of such as N, P, K, Ca, Zn, B, S, increased soil $\mathrm{pH}$ levels as well as cation exchange capacity (CEC); a weakened foundation for high yielding sustainability farming, and escalating remedial cost on rebuilding depleted soil fertility evaluation (analysis). The decline in soil fertility has imposed a national problem of food insecurity [3]. Therefore, this study was conducted to assess the soil fertility of project sites of the Lower Benue River Basin Development Authority project sites (LBV; coordinates of longitudes $7^{\circ} 00^{\prime} \mathrm{E}$ and $8^{\circ} 30^{\prime} \mathrm{E}$ and latitudes $5^{\circ} 00^{\prime} \mathrm{N}$ and $6^{\circ} 30^{\prime} \mathrm{N}$ ) in Makurdi, Otukpo and Katsina-Ala areas of Benue State (Middle belt Nigeria) with a view to determine the soil physical, chemical parameters and the essential nutrients of the soil.

\section{Materials and Method}

\subsection{Description of the Study Area}

The study was conducted in three projects sites of Lower Benue River Basin Development Authority located at Otukpo, Makurdi and Katsina-Ala LGA of Benue State, Nigeria. Figures 1-3 show soil sampling locations.

\subsection{Sample Collection}

Soil samples were collected from three farm sites namely; Otukpo site (Otukpo 


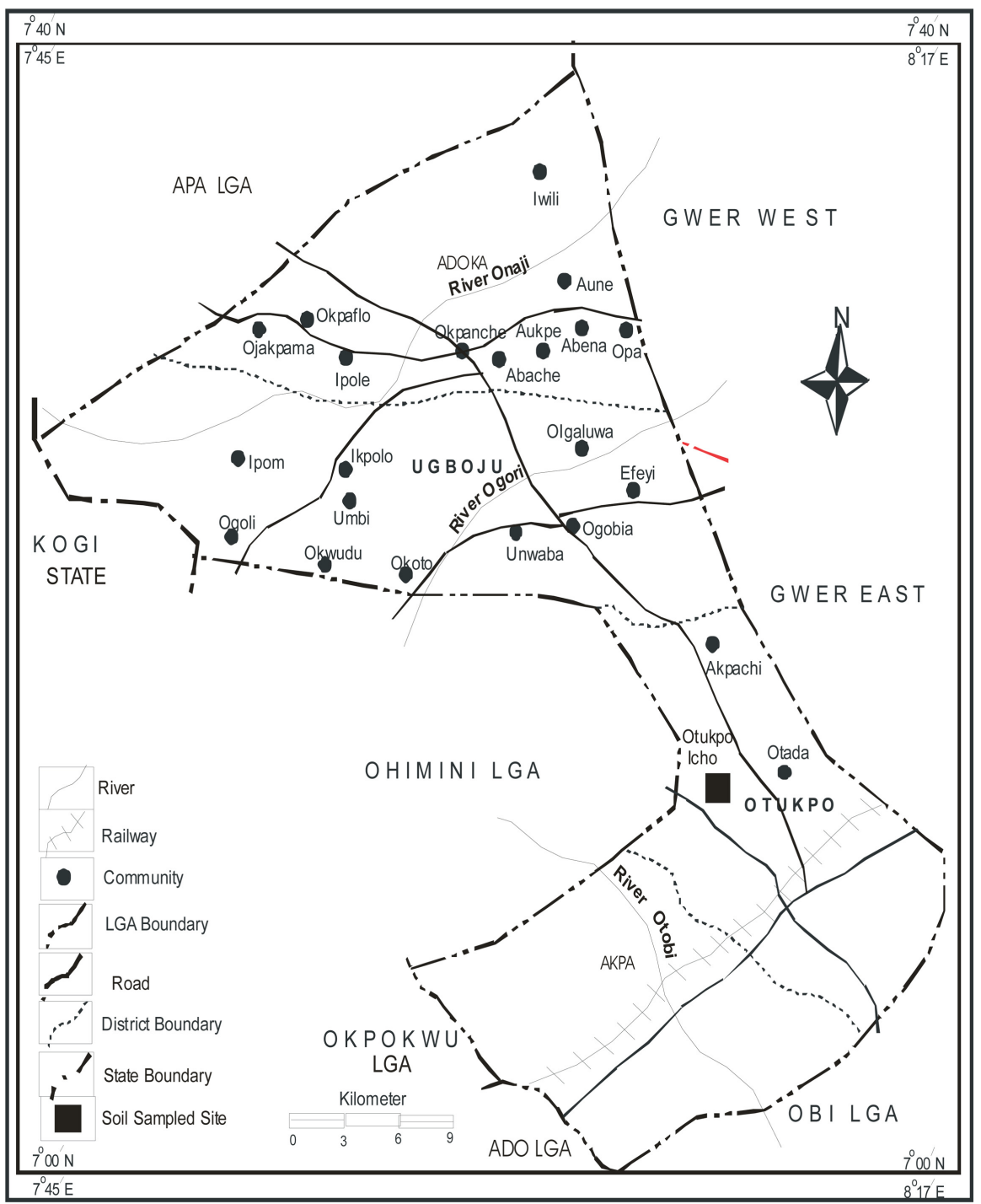

Figure 1. Map of otukpo local government area showing soil sampled site. Source: Ministry of lands and survey Makurdi, 2013.

LGA), Makurdi site (Makurdi LGA) and Katsina-Ala (Katsina-Ala LGA) during the dry season of 2020. A total of twenty seven (27) soils samples were obtained. Nine (9) soil samples from each farm site, using a spiral auger of $2-5 \mathrm{~cm}$ diameter, in each of the site, soil samples were collected at a depth of about $0-15$ $\mathrm{cm}$ during the dry season (November-April) were stored in a clean black polyethylene bag and transported to the laboratory.

\subsection{Sample Preparation and Treatment}

All soil samples obtained from each of the farm project sites were dried for (72 hours) at room temperature $\left(25^{\circ} \mathrm{C}\right)$. The air dried soil samples were pounded using pestle and mortal to ensure homogeneity. The samples were sieved through a $2 \mathrm{~mm}$ mesh sieve. The air dried soil samples were stored in clean black polyethylene bags and sealed awaiting digestion and analysis. 


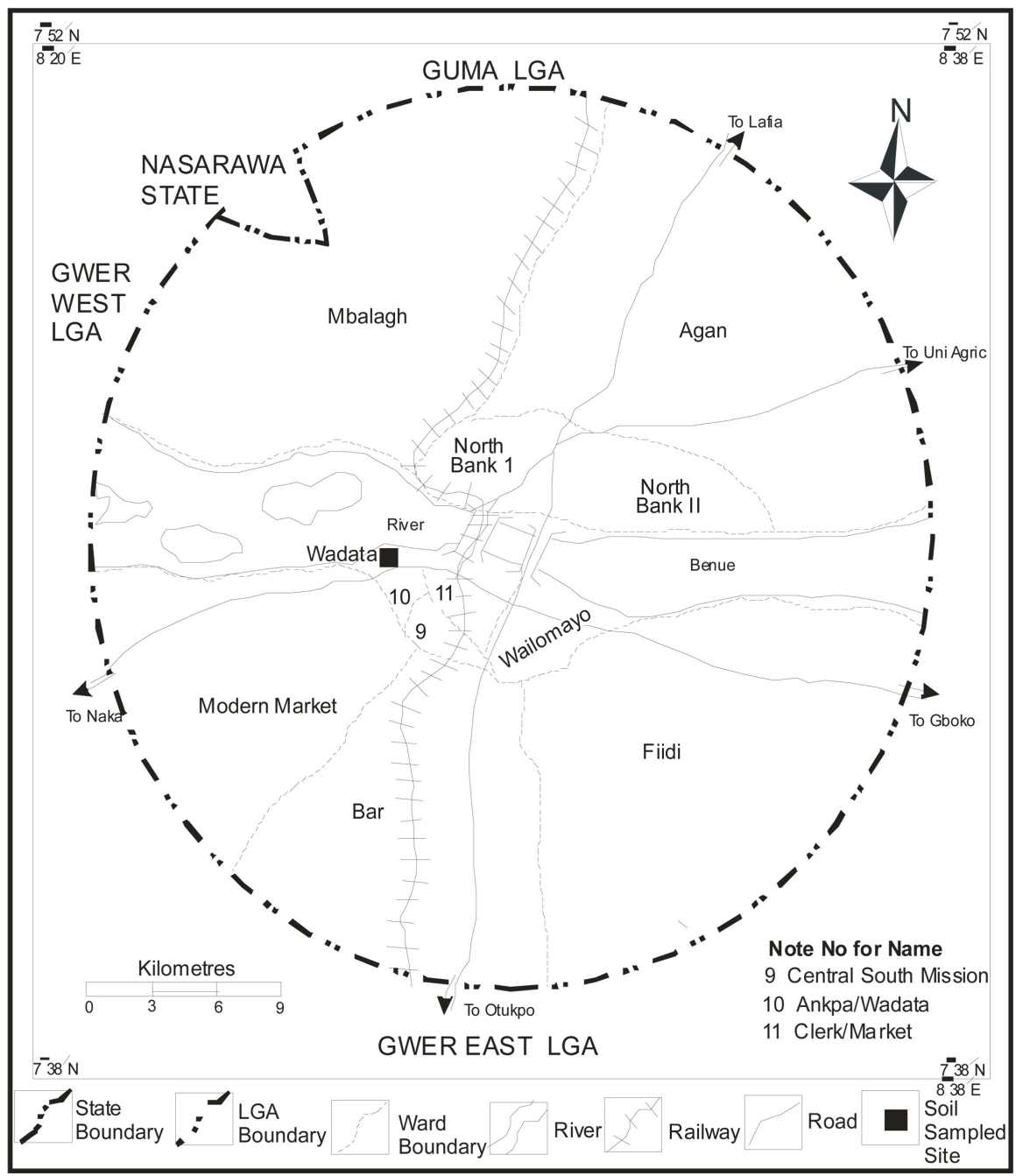

Figure 2. Map of Makurdi local government showing soil sample site. Source: Ministry of lands and survey Makurdi.

\subsection{Soil Analysis}

\subsubsection{Particle Size Analysis}

Particle size analysis was conducted using the Bouyoucous hydrometer method [9].

\subsubsection{Soil pH}

The $\mathrm{pH}$ was determined by taking $10 \mathrm{~g}$ of soil sample in the $50 \mathrm{ml}$ beaker and 10 $\mathrm{ml}$ of distilled water was added. The suspension was well stirred and allowed to settle for 30 mins undisturbed. $\mathrm{pH}$ readings of the suspension were taken using $\mathrm{pH}$ meter [10].

\subsubsection{Cation Exchange Capacity (CEC)}

The cation exchange capacity was determined using ammonium saturation method where $5 \mathrm{~g}$ of soil was saturated with normal ammonium acetate solution after which it was leached in the filter paper. The filter paper was distilled in 30 $\mathrm{ml}$ of distilled water, $15 \mathrm{ml}$ of sodium hydroxide and the distillate was received 


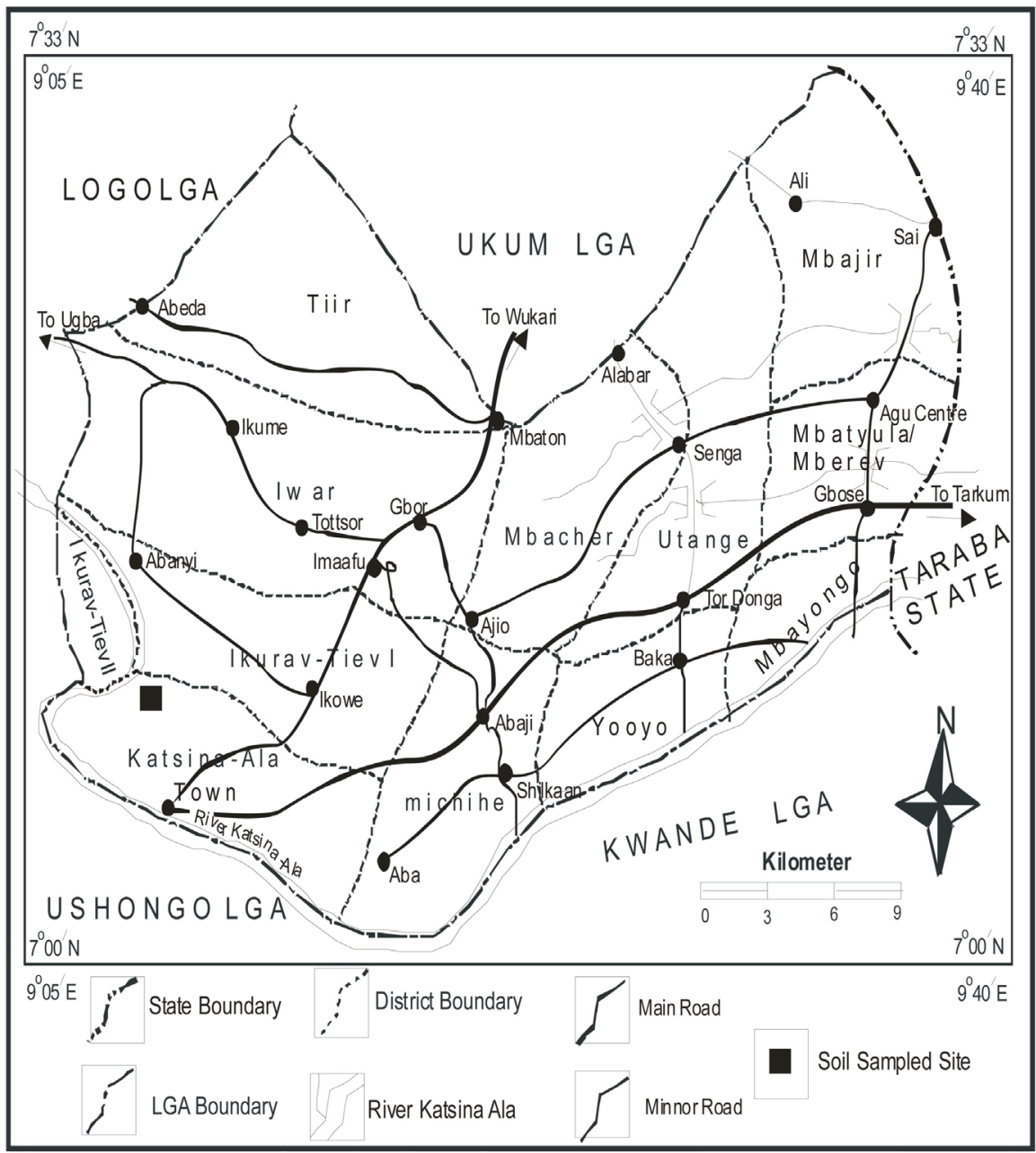

Figure 3. Map of Katsina-Ala local government area showing soil sample site. Source: Ministry of lands and survey Makurdi.

in $20 \mathrm{ml}$ of Boric acid and titrated against the standard hydrochloric acid solution $(0.1 \mathrm{~N})$.

\subsubsection{Calcium and Magnesium Determination}

Calcium and Magnesium were determined by the EDTA method where $19 \mathrm{ml}$ of the distilled water was added in a $1 \mathrm{ml}$ aliquot to make $20 \mathrm{ml}$ solution. $1 \mathrm{ml}$ of $10 \%$ sodium hydroxide $(\mathrm{NaOH})$ and three drops of potassium cyanide, hydroxyl amine hydrochloride and triethanol amine reagents were added, this is followed by adding 2 - 3 drops of murexid indicator and finally titrated using EDTA where the solution changed from pink to purple for calcium determination. The other important element called magnesium was determined using 2 - 3 drops of Eriochrome Black $\mathrm{T}$ indicator in which the purple color changed to blue after titration [10].

\subsubsection{Sodium and Potassium}

The filtrate solution from CEC determination was used to determine the concentration of sodium and potassium ions by flame photometer. 


\subsubsection{Organic Carbon}

Organic carbon was determined by Walkey-Black method (1934) where $10 \mathrm{ml}$ of $1 \mathrm{~N}$ potassium dichromate $\left(\mathrm{K}_{2} \mathrm{Cr}_{2} \mathrm{O}_{7}\right)$ solution and $10 \mathrm{ml}$ of sulphuric acid $\left(\mathrm{H}_{2} \mathrm{SO}_{4}\right)$ where pour in a conical flask containing a $1 \mathrm{~g}$ of soil and was allowed to stand for 30 minutes after shaking. $50 \mathrm{ml}$ of distilled water, $5 \mathrm{ml}$ of orthophosphoric acid and 1 - 3 drops of barium diphenyl indicator were added differently in which the light brown colour of the solution turned to maroon after titration with ferric sulphate $\left(\mathrm{FeSO}_{4}\right)$ solution [10].

\subsubsection{Total Nitrogen}

A micro-Kjeldhal distillation method was used for Nitrogen determination where $2 \mathrm{~g}$ of soil samples were taken into the digestion flask. One selenium catalyst tablet (Kjeldhal Catalyst) was added to $10 \mathrm{ml}$ of concentrated sulphuric acid $\left(\mathrm{H}_{2} \mathrm{SO}_{4}\right)$. The flask was put in the digestion block for heating to about an hour and was allowed to cool. Distilled water was added to the digest and to make it $30 \mathrm{ml}$, out of which $10 \mathrm{ml}$ was taken for distillation in Kjeldhal flask plus $15 \mathrm{ml}$ and $30 \mathrm{ml}$ of sodium hydroxide $(\mathrm{NaOH})$ solution and distilled water respectively. The distillate was received in a $20 \mathrm{ml}$ of boric acid indicator. The distillate was titrated with $0.01 \mathrm{~N}$ sulphuric acid $\left(\mathrm{H}_{2} \mathrm{SO}_{4}\right)$.

\subsubsection{Available Phosphorus}

A spectrophotometer with absorbance at $660 \alpha$ was used in determining the available phosphorus using Bray no $1\left(0.03 \mathrm{~N} \mathrm{NH}_{4} \mathrm{~F}+0.025 \mathrm{NH}_{4} \mathrm{Cl}\right)$ method where $5 \mathrm{ml}$ of Bray no 1 extract was added into a flat bottom flask containing of $2 \mathrm{~g}$ of soil. $2 \mathrm{ml}$ of ammonium molybdate solution and $1 \mathrm{ml}$ of dilute standard chloride were added to the soil solution and shake vigorously in which it changed from colorless to light blue. Reading from the spectro-photometer was obtained.

\subsubsection{Electrical Conductivity}

Electrical conductivity of the samples was determined using conductivity meter method. $50 \mathrm{ml}$ of distilled water were added to $10 \mathrm{~g}$ of soil sample in a beaker and shook up using hand. The reading values were obtained from the matter.

\subsection{Determination Soil Organic Matter}

Soil Organic matter was determined using Anne method (Modified Walkey-Black Method) [11]. The crucible was weighed using analytical weighing balance. Also, $5 \mathrm{~g}$ of the soil sample was weighed and both weights were added together and recorded on logbook. After which the weighed soil sample was put in the weighed crucible and placed in a furnace for ashing at a temperature of $1000^{\circ} \mathrm{C}$ for 1 (one) hour, after which the furnace was put off and the sample was removed and re-weighed. The method used is known as gravimetric method. The soil organic matter was calculated using the formula below.

$$
\% \text { soil organic matter }=\frac{\text { mass before ashing }}{\text { mass after ashing }} \times 100
$$




\subsubsection{Soil Bulk Density and Percentage Soil Porosity Measurements}

The soil sample of $10 \mathrm{~g}$ was sieved, weighed and put into a calibrated test tube. Then $5 \mathrm{~mL}$ of water was added gradually and in drops into the test tube containing the soil sample and the soil was allowed to absorb the water molecules until it is fully saturated without allowing the water volume to come above the soil level in the test tube. The soil bulk density was calculated using the formula below.

$$
\text { Bulk density }=\frac{\text { mass of soil sample }}{\text { volume of water added }}
$$

The soil porosity was obtained from bulk density, using the formula stated below

$$
\% \text { soil porosity }=\frac{\text { volume of water added }}{\text { weight of soil sample }} \times 100
$$

\subsubsection{Soil Moisture Content Determination}

The soil sample of $5 \mathrm{~g}$ was weighed and put into a weighed glass Petri-dish, using analytical weighing balance ad both weights were recorded on logbook. Then the sample was placed in an oven at a temperature of $70^{\circ} \mathrm{C}$ for $5 \mathrm{hr}$ to completely dry off the wet soil. The dried soil sample was re-weighed. Then the difference between the initial weight (before heating) and final (after heating) was taking and recorded. The method used is gravimetric method. And the moisture content was calculated using the formula stated below.

$$
\% \text { Moisture content }=\frac{M_{1}-M_{2}}{M_{1}} \times 100
$$

where $M_{1}$ is initial mass of wet sample; $M_{2}$ is final mass of dried sample.

\subsection{Data Treatment}

Data collected were subjected to statistical test of mean, standard deviation, range to assess significant variation in concentration level of the various samples. Statistical analysis was performed using SPSS.

\section{Results and Discussion}

\subsection{Results}

Results of soil physical, chemical parameter and essential nutrients in the Lower Benue River Basin Development Authority (LBRBDA) Project sites are shown in Tables 1-3.

\subsection{Discussion}

Particle size distribution has shown higher content of sand proportion ranging from $63.7 \% \pm 0.71 \%-70 \% \pm 0.32 \%$; site " $\mathrm{B}$ " has the highest sand proportion while site " $\mathrm{A}$ " has the lowest. With moderate clay proportion ranging from $20.9 \% \pm 0.05 \%-25.20 .50 \%$ and the proportion of silt is the lowest ranging from $9.1 \% \pm 0.20 \%-11.1 \% \pm 0.10 \%$. The dominance of sand proportion reflects that, 
Table 1. Soil physical parameters from lower Benue river basin development authority.

\begin{tabular}{|c|c|c|c|c|c|}
\hline \multirow[t]{2}{*}{ Parameter } & \multicolumn{3}{|c|}{ Site } & \multirow[t]{2}{*}{ Range } & \multirow[t]{2}{*}{ SRNS } \\
\hline & A & B & C & & \\
\hline Sand (\%) & $63.7 \pm 0.71$ & $70.0 \pm 0.32$ & $65.0 \pm 0.08$ & $53.7-90.0$ & - \\
\hline Clay (\%) & $25.2 \pm 0.50$ & $20.9 \pm 0.05$ & $24.7 \pm 0.02$ & $12.3-35.2$ & - \\
\hline Silt (\%) & $10.3 \pm 0.41$ & $9.1 \pm 0.20$ & $11.1 \pm 0.10$ & $7.9-13.1$ & - \\
\hline Porosity (\%) & $34.0 \pm 0.07$ & $42.0 \pm 0.07$ & $39.5 \pm 0.06$ & $23.5-61.7$ & $30-60$ \\
\hline Bulk Density $\left(\mathrm{g} / \mathrm{cm}^{3}\right)$ & $0.99 \pm 0.02$ & $1.05 \pm 0.05$ & $1.01 \pm 0.01$ & $0.72-3.12$ & $0.1-1.60$ \\
\hline $\begin{array}{c}\text { Moisture } \\
\text { Content (\%) }\end{array}$ & $0.12 \pm 0.55$ & $1.15 \pm 0.04$ & $0.36 \pm 0.01$ & $0.87-2.87$ & $15.00-30.00$ \\
\hline Organic matter (\%) & $3.21 \pm 0.07$ & $0.67 \pm 0.01$ & $1.26 \pm 0.02$ & $0.56-4.89$ & $2.00-3.00$ \\
\hline
\end{tabular}

Key: SRNS: Standard Rating of Nigeria Soil; Site A: Otukpo; Site B: Makurdi; Site C: Katsina-Ala.

Table 2. Chemical parameters of soil samples from lower Benue river basin development authority.

\begin{tabular}{cccccc}
\hline Parameter & \multicolumn{2}{c}{ Site } & & Range & SRNS \\
\hline & A & B & C & & \\
\hline $\mathrm{pH}$ & $5.84 \pm 0.030$ & $6.14 \pm 0.010$ & $6.32 \pm 0.040$ & $4.03-7.91$ & $5.50-7.50$ \\
CEC (meq/100g) & $2.022 \pm 0.04$ & $2.253 \pm 0.002$ & $2.286 \pm 0.002$ & $1.73-4.90$ & $8.00-10.00$ \\
Base Saturation (\%) & $0.246 \pm 0.03$ & $0.253 \pm 0.002$ & $0.286 \pm 0.004$ & $0.131-0.463$ & - \\
$\begin{array}{c}\text { Conductivity } \\
(\mathrm{mS} / \mathrm{m})\end{array}$ & $31.00 \pm 0.350$ & $44.00 \pm 0.20$ & $54.00 \pm 0.35$ & $27.00-64.00$ & $30.00-60.00$ \\
\hline
\end{tabular}

Key: SRNS: Standard Rating of Nigeria Soil; Site A: Otukpo; Site B: Makurdi; Site C: Katsina-Ala.

Table 3. Essential nutrients/elements of soil samples from lower Benue river basin development authority.

\begin{tabular}{cccccc}
\hline $\begin{array}{c}\text { Essential element } \\
(\mathrm{mg} / \mathrm{L})\end{array}$ & A & Site & Range & SRNS \\
& B & C & & \\
Nitrogen & $6.56 \pm 0.36$ & $3.18 \pm 0.01$ & $7.20 \pm 0.14$ & $2.40-9.89$ & $0.04-0.08$ \\
Phosphorous & $3.74 \pm 0.03$ & $5.01 \pm 0.04$ & $2.57 \pm 0.05$ & $1.37-7.85$ & $13-25$ \\
Calcium & $19.80 \pm 0.85$ & $20.50 \pm 1.06$ & $22.04 \pm 0.73$ & $12.25-25.21$ & $>3.2$ \\
Potassium & $29.22 \pm 0.72$ & $28.85 \pm 1.45$ & $29.28 \pm 0.91$ & $19.04-31.94$ & $>3.2$ \\
Magnesium & $8.62 \pm 0.44$ & $9.07 \pm 0.06$ & $12.08 \pm 0.13$ & $6.73-15.08$ & $>3.2$ \\
\hline
\end{tabular}

Key: SRNS: Standard Rating of Nigeria Soil; Site A: Otukpo; Site B: Makurdi; Site C: Katsina-Ala.

the parent material of the soil is coarse, while the clay and silt content could be attributed to the sorting of soil materials by biological and/or agricultural activities or surface erosion. Thus the soil may be prone to leaching due to high sand content. From available data on Table 1, it can be said, the particle size distribution falls within the range of a fertile soil.

Percentage (\%) soil porosity ranges from $34.0 \% \pm 0.07 \%-49.5 \% \pm 0.06 \%$. Sample from site "A" has the lowest soil porosity, while sample from site "B" has 
the highest soil porosity. Soil porosity is the total pore-space. Porosity is directly related to soil permeability-refers to the ease with which water and air move through soil depending on texture, structure and organic matter content [2]. Table 1 shows the porosity values, it can be inferred that the soil holding capacity falls within the range of a fertile soil.

Percentage (\%) moisture content ranges from $0.12 \% \pm 0.55 \%-1.15 \% \pm 0.04 \%$. Sample from site " $A$ " has the lowest moisture content, while sample from site " $\mathrm{B}$ " has the highest moisture content. Moisture content is the measure of the water holding capacity of soil. This is due to the high proportion of the sand particles, low organic matter content and low \% clay in the soil. Hence, the higher the moisture content, the higher the organic and clay content and the more fertile the soil. Moisture influences the rate of nutrients uptake by plants from the soil. From the moisture content values provided on Table 1, it can be stated that the moisture content is within the acceptable range of a fertile soil.

Organic matter content ranges from $0.67 \% \pm 0.01 \%-3.21 \% \pm 0.07 \%$. Sample from site " $\mathrm{B}$ " has the lowest organic matter content, while sample from site " $A$ " has the highest organic matter content. Soil organic matter refers to any plant or animal remains that return to the soil through decomposition processes. This is as a result of the continuous use of herbicide on the farmland and indiscriminate bush burning. Table 1 also provides data on organic matter content, it indicates that site $\mathrm{A}$ has higher organic matter than sites $\mathrm{B}$ and $\mathrm{C}$.

Bulk density ranges from $0.99 \pm 0.02 \mathrm{~g} / \mathrm{cm}^{3}-1.05 \pm 0.01 \mathrm{~g} / \mathrm{cm}^{3}$. Sample from site " $\mathrm{A}$ " has the lowest bulk density, while sample from site " $\mathrm{B}$ " has the highest bulk density. Bulk density is an indication of soil compaction-reflecting the soil ability to function for structural support, water and soil aeration. This can be attributed to the high sand proportion and low clay content of the soil. From the bulk density data on Table 1, it shows that bulk density falls within the acceptable range of fertile soil [12].

The $\mathrm{pH}$ of the soil samples ranges from $5.84 \pm 0.03-6.32 \pm 0.04$; hence sample from site " $\mathrm{C}$ " has the highest $\mathrm{pH}$ while sample from site " $\mathrm{A}$ " has the lowest $\mathrm{pH}$. Soil $\mathrm{pH}$ is slightly acidic, this is attributed to the accumulation of $\mathrm{H}^{+}$and $\mathrm{Al}^{3+}$ due to poor farm practice. Nutrients availability is greatly influenced by $\mathrm{pH}$ levels, nutrients are most available to plants in optimum $\mathrm{pH}$ range of 5.5 - 7.5. generally, macronutrients including Nitrogen (N), Potassium (K), Sulphur (S), Calcium (Ca) and Magnesium ( $\mathrm{Mg}$ ) are mostly available in slightly acidic to moderately alkaline soils, while the availability of micronutrients such as Iron $(\mathrm{Fe})$. Maganese (Mg), Boron (B), Copper $(\mathrm{Cu})$, and Zinc $(\mathrm{Zn})$ increases in moderate acidic soil [13]. But some exceptions are applicable. In addition to nutrients availability controlled by $\mathrm{pH}$, microorganism activities that contribute to the decomposition of organic materials are also influenced by $\mathrm{pH}$ levels. From the result provided in Table 2, it can be inferred that the soil the $\mathrm{pH}$ is good, since it falls within the range of a fertile soil.

Cations exchange capacity (CEC) ranges from $2.022 \pm 0.04 \mathrm{meq} / 100 \mathrm{~g}-2.286 \pm$ 
$0.002 \mathrm{meq} / 100 \mathrm{~g}$. Sample from site "A" has the lowest CEC, while sample from site "C" has the highest CEC. This is the measure of the ability of soil to attract, retain and exchange cationic elements at a particular $\mathrm{pH}$. In order for soil to absorb available nutrients, the nutrients must be dissolved and when dissolved they are in form of ions (meaning they possess electrical charges). The CEC values of the soil are low, due to low clay, organic matter content, sand proportion and consequently the poor water holding capacity of the soil. CEC is influenced by the amount of $\mathrm{pH}$. Hence $\mathrm{CEC}$ is a direct indication of available soil nutrients. CEC for a fertile soil ranges from $(8-10) \mathrm{meq} / 100 \mathrm{~g}$. From CEC data provided in Table 2 shows that the CEC is low since it is below the acceptable range for a fertile soil.

Percentage (\%) Base saturation ranges from $0.246 \% \pm 0.03 \%-0.286 \% \pm$ $0.004 \%$. Sample from site " $A$ " has the lowest \% base saturation, while sample from site "C" has the highest \% base saturation. Base saturation is the measure of the proportion of the total CEC occupied by basic cations. Hence higher the clay and organic matter content the more fertile the soil and vice-versa. Table 2 indicates that the $\%$ base saturation is low due to the low organic matter content.

Soil electrical conductivity (EC) ranges from $31 \pm 0.350 \mathrm{mS} / \mathrm{m}-54 \pm 0.35$ $\mathrm{mS} / \mathrm{m}$. Sample from site "A" has the lowest EC, sample from site "C" has the highest EC. This is the measure of the ability of the soil to conduct electrical current. EC is an indication of nutrients availability in the soil. The higher the EC, the more clay and organic matter particles in the soil and hence, the more cations that are being held in the soil and higher the nutrients content in the soil. While the lower the EC the lower the nutrients in the soil. But the EC should not be excessive as such will result in a detrimental effect on the soil fertility. EC is influenced by numerous soil properties such as texture, salanity and moisture. From the values on Table 2, it shows that the soil has an acceptable EC [13] [14].

Nitrogen $(\mathrm{N})$ content ranges from $3.18 \pm 0.01 \mathrm{mg} / \mathrm{L}-7.20 \pm 0.14 \mathrm{mg} / \mathrm{L}$. sample from site " $\mathrm{B}$ " has the lowest nitrogen content, while that from site " $C$ " has the highest nitrogen content. Nitrogen is a part of protein, enzyme, and chlorophyll which also serves as a regulator. From the result of analysis on Table 3, it indicates that the content of nitrogen is high since it falls above the recommended range for a fertile soil. Hence, it can be said that the soil is highly rich in nitrogen and very fertile for agricultural use. This could be as a result the continuous application nitrogen containing fertilizer.

Available phosphorous $(\mathrm{P})$ ranges from $2.57 \pm 0.05 \mathrm{mg} / \mathrm{L}-5.01 \pm 0.04 \mathrm{mg} / \mathrm{L}$. Sample from site " $C$ " has the lowest Phosphorous content, while that from site " $B$ " has the highest phosphorous content. From the data provided on Table 3, it shows that the phosphorous content is low since it falls below the range of acceptable fertile soil. This could be due to the slightly acidic $\mathrm{pH}(<6.5)$ which is not suitable for solubility and release of phosphorous in the soil. From literature macronutrients are usually less available in soil with low $\mathrm{pH}$ [14] [15].

Calcium $(\mathrm{Ca})$ content ranges from $19.80 \pm 0.85 \mathrm{mg} / \mathrm{L}-22.04 \pm 0.73 \mathrm{mg} / \mathrm{L}$. The 
sample from site "A" has the lowest calcium content, while that from site "C" has the highest calcium content. From the analytical result on Table 3, it can be inferred that the high Calcium (Ca) content indicates the presence of suspected dolomite, gypsum, as well as the use of lime on the soil. As such the soils are rich in calcium [16].

Potassium (K) content of the soil samples ranges from $28.85 \pm 0.72 \mathrm{mg} / \mathrm{L}$ $29.28 \pm 0.98 \mathrm{mg} / \mathrm{L}$. The soil sample from site "B" has the lowest Potassium $(\mathrm{K})$ content, while soil sample from site "C" has the highest Potassium (K) content. It can be inferred from the result on Table 3 that the Potassium content is high when compared with SRNS.

Magnesium (Mg) contents of the soil samples ranges from $8.62 \pm 0.44 \mathrm{mg} / \mathrm{L}$ $12.08 \pm 0.13 \mathrm{mg} / \mathrm{L}$. Sample from site "A" has the lowest Magnesium $(\mathrm{Mg})$ content, while sample from site " $\mathrm{C}$ " has the highest Magnesium $(\mathrm{Mg})$ content. The result on Table 3 shows that Magnesium $(\mathrm{Mg})$ content is far above 3.2 hence the farm sites are rich in $\mathrm{Mg}$ [17] [18].

\section{Conclusion}

The study revealed that LBRBDA project sites is enriched with nutrients which could be as a result of climatic, weather, human activities and geological formation in the area. Levels of essential nutrients in the three sites (A, B and C) has shown that these project sites do support vegetable crop and animal production and in turn supports a variety of life forms such as microscopic bacterial to higher forms of life including invertebrates such as moles, ants, mites, nematodes earthworms. Results obtained conform to results from other studies.

\section{Conflicts of Interest}

The authors declare no conflicts of interest regarding the publication of this paper.

\section{References}

[1] Jimoh, A.I., Yusuf, Y.O. and Yau, S.L. (2014) Soil Suitability Evaluations for Rain Maize Production, Northern Nigeria. Unpublished M.Sc. Thesis, Department of Geography, ABU Zaria.

[2] Johnny, J. (2011) Assessing Soil Fertility: The Importance of Soil Fertility and Its Interpretation: Law Trust Senior Fellow. Rothamsted Research, Harppenden AL5 UK, 2, 11-20.

[3] Umar, B., Idris, S., Ali, S., Abdullahi, B.U. and Aliyu, M.D. (2018) Evaluation of Indigenous Soil Fertility Assessment of the Sudan Savannah Agro-Ecological Zone of Nigeria-A Paper Review. Journal of Agriculture and Veterinary Science, 11, 1-9.

[4] Uriyo, A.P., Mongi, H.O., Chowdhury, M.S., Singh, B.R. and Semoka, J.M.R. (1979) Introductory Soil Science. Tanzania Pul. House, Daressalam, p. 232.

[5] Abraham, E.A., Osemeahon, S.A., Mohammed, B. and Bawa, A. (2014) Assessing the Soil Fertility Status of Three Selected Rice Farms in Yola Metropolis, Adamawa State, Nigeria. International Journal of Current Microbiology and Applied Sciences, 3, 648-665. 
[6] De Timmerman, L., Waegeneers, N., Thiry, C., Du Laing, G., Tack, F. and Ruttens, A. (2014) Selenium Contents of Belgian Cultivated Soils and Its Uptake by Field Crops and Vegetables. Science of the Total Environment, 468-469, 77-82. https://doi.org/10.1016/j.scitotenv.2013.08.016

[7] Esu, I.E. (1991) Detailed Soil Survey of NIHORT farm at Bunkure, Kano State. A Cosultancy Study Project Commissioned by the Nigerian Horticultural Research Nigeria, p. 72.

[8] Corbeels, M., Shiferaw, A. and Haile, M. (2000) Farmer's Knowledge of Soil Fertility and Local Management Strategies in Tigray, Ethiopia. Managing Africa's Soils No. 10.

[9] Soil Survey Staff (1996) Soil Survey Laboratory Method Manuals. Soil Survey Investigation Reports No. 4. Version 3.

[10] Mathieu, C. and Pieltain, F. (2003) Chemical Analysis of Soils. Selected Methods, France, p. 387.

[11] McLean, E.O. (1982) Soil pH and Lime Requirement. In: Keeney, Ed., Methods of Soil Analysis, Chemical and Microbiological Properties, 2nd Edition, American Society of Agronomy, Madison, 199-227.

[12] Danica, F. (2012) Evaluation of Soil Quality Parameters Development in Terms of Sustainable Land Use. http://creativecommons.org/licenses/by/3.0

[13] Clain, J. (2016) Plant Nutrition and Soil Fertility, MSU Extension Soil Fertility Specialist, and Kathrin Olson-Rutz, Research Associate, 1-12.

[14] Brar, M.S. and Dinesh, K.B. (2009) Evaluation of Soil Fertility and Partial Nutrient Balance for Improve Fertilizer Recommendations Under Intensive Agriculture in India. Journal of Soil Science and Environmental Management, 4, 55-60.

[15] Akinrinde, E.A. (2006) Issues of Optimum Nutrient Sustainable Crop Productionin Tropical Developing Countries. Pakistan Journal, 5, 387-397. https://doi.org/10.3923/pjn.2006.387.397

[16] Chikezie, I.A., Eswaran, H., Asawalam, D.O. and Ano, A.O. (2017) Characterization of Two Benchmark Soil of Contracting Parent Materials in Southern Nigeria. Global Journals of Pure and Applied Sciences, 16, 23-29. https://doi.org/10.4314/gjpas.v16i1.66190

[17] Nafiu, A.K., Abiodun, M.O., Okpara, I.M. and Chude, V.O. (2012) Soil Fertility Evaluation: A Potential Tool for Predicting Fertilizer Requirement for Crops in Nigeria. African Journal of Agricultural Research, 7, 6204-6214.

[18] Ekpe, I.I., Uzoho, B.U., Ahukaemere, C.M. and Okere, S. E. (2017) Assessment of Fertility Status of Irrigated Lowland Rice Growing Soils of Ebonyi South-East Nigeria. Environment and Ecology Research, 5, 476-479.

https://doi.org/10.13189/eer.2017.050702 